5 Caio C. Aragon ${ }^{1}$, Cesar Mateo ${ }^{2}$, Ana I. Ruiz-Matute ${ }^{3}$, Nieves Corzo ${ }^{3}$, Gloria Fernandez-

6 Lorente $^{3}$, Laura Sevillano ${ }^{4}$, Margarita Díaz ${ }^{4}$, Rubens Monti ${ }^{5}$, Ramón I. Santamaría 7 and Jose M. Guisan ${ }^{2 *}$

8

9 1.- Instituto de Química, UNESP - Univ. Estadual Paulista, Departamento de

\section{PRODUCTION OF XYLO-OLIGOSACCHARIDES}

\section{BY IMMOBILIZED-STABILIZED DERIVATIVES OF}

\section{ENDO-XYLANASE FROM Streptomyces halstedii}

\begin{abstract}
Bioquímica e Tecnologia Química, Araraquara, SP, Brazil.
\end{abstract}
2.- Instituto de Catálisis. ICP-CSIC. Campus UAM. 28049 Madrid. Spain.

3.- Instituto de Investigación en Ciencias de la Alimentación (CIAL) CSIC-UAM 28049 Madrid. Spain.

4.- Instituto de Biología Funcional y Genómica. Departamento de Microbiología y Genética. Salamanca, Spain.

5.- Faculty of Pharmaceutical Sciences, UNESP - Univ Estadual Paulista, Department of Food and Nutrition, Araraquara, SP, Brazil.

Corresponding author:

Jose M. Guisan

imguisan@icp.csic.es

Tel: + 3491585 4809; Fax: +34 915854760 
An endoxylanase from Streptomyces halstedii was stabilized by multipoint covalent immobilization on glyoxyl-agarose supports. The immobilized enzyme derivatives preserved $65 \%$ of the catalytic activity corresponding to the one of soluble enzyme that had been immobilized. These immobilized derivatives were 200 times more stable 200 times more stable than the one-point covalently immobilized derivative in experiments involving thermal inactivation at 60 ?C. The activity and stability of the immobilized enzyme was higher at $\mathrm{pH} 5.0$ than at $\mathrm{pH}$ 7.0. The optimal temperature for xylan hydrolysis was 10 ? higher for the stabilized derivative than for the non-stabilized derivative. On the other hand, the highest loading capacity of activated $10 \%$ agarose gels was $75 \mathrm{mg}$ of enzyme per $\mathrm{mL}$ of support. To prevent diffusional limitations, low loaded derivatives (containing $\mathbf{0 . 2} \mathbf{~ m g}$ of enzyme per $\mathrm{mL}$ of support) were used to study the hydrolysis of xylan at high concentration (close to $1 \% \mathrm{w} / \mathrm{v}) .80 \%$ of the reducing sugars were released after 3 hours at 55 ?C. After 80 $\%$ of enzymatic hydrolysis, a mixture of small xylo-oligosaccharides was obtained (from xylobiose to xylohexose) with a high percentage of xylobiose and minimal amounts of xylose. The immobilized-stabilized derivatives were used for 10 reaction cycles with no loss of catalytic activity.

Keywords: Multipoint covalent immobilization of enzymes, Thermo-stabilization of endoxylanases, Production of xylo-oligosaccharides, hydrolysis of xylan 
47 Xylo-oligosaccharides (XOS) are interesting prebiotics that are the subject of growing interest ${ }^{[1]}$. For example, a recent comparison of the prebiotic effect of several oligosaccharides concluded that XOS promotes an increase in the number of Bifidobacteria $^{[2]}$.

XOS can be obtained by chemical or enzymatic hydrolysis of xylan. Xylan (in the form of branched and modified arabinoxylan) is the major component of hemicellulose, one of the most abundant polysaccharides in the vegetal world ${ }^{[3]}$. Consequently, vegetal wastes can be converted to an important prebiotic ingredient. Enzymatic protocols that utilize endoxylanases for catalysis reactions are advantageous due to the absence of undesirable by-products (eg., furfural) [4-8].

The use of immobilized-stabilized derivatives of endoxylanases may be a very useful method for generating XOS. The biocatalyst could be reused for many reaction cycles at high temperatures (e.g. 50-60 a C) High temperatures may be necessary to dissolve high concentrations of xylan, to prevent microbial contaminations and to increase the reaction rates. The utilization of immobilized derivatives also facilitates the careful design of reactor and control of the degree of hydrolysis to produce the most suitable mixture of different XOS (xylobiose, xylotriose, xylotetraose, etc.). In spite of these relevant advantages, protocols for immobilization and stabilization of endoxylanases have been hardly reported.

Enzymes under the name xylanase include proteins that break down the hemicellulose polysaccharide, beta-1,4-xylan, of the vegetal cell wall. In nature, these 
enzymes are widely distributed as they function to aid in the growth of plants and microorganisms. For example, in fungi, xylanase enzymes degrade plant biomass to be utilized as a source of nutrients. Although humans do not produce xylanases, these enzymes are commercially utilized for a number of purposes; these processes include increasing the digestibility of animal feed [9], eliminating contaminant steps while obtaining white pulp [10] and improving the texture of bread dough [11].

Bacteria of the genus Streptomyces are saprophytic organisms that degrade a wide range of insoluble substrates using an arsenal of extracellular hydrolytic enzymes. Among these enzymes are the xylanases. The production of these xylanases has been reported in a number of Streptomyces strains that have been isolated from different sources. One such strain, originally isolated from agricultural waste, is S. halstedii JM8. S. halstedii JM8 produces an extracellular $45 \mathrm{kDa}$ modular xylanase (Xys1 L) that contains a catalytic domain and a cellulose binding domain that is separated by a linker region. Extracellular serine proteases cleave the xylanase thus liberating the catalytic domain (Xys1S of $33.7 \mathrm{kDa}$ ). This catalytic domain has been shown to exhibit the same activity against xylan in vitro as than the complete protein [12]. The deletion of a Gly-rich like region located in the carboxy terminus of the Xys1S [13-14] generates a $32.6 \mathrm{kDa}$ protein that has previously been utilized for microcalorimetric and crystallization studies [15] and has been modified with a hexa-His tag at its carboxy terminus.

In this paper, a poly-His tagged catalytic domain of Streptomyces halstedii JM8 endoxylanese was purified by using tailor-made immobilized metal chelates (IMAC 
91 chromatography). The purified domain was then immobilized by multipoint covalent attachment on highly activated glyoxyl-agarose supports under alkaline conditions. This immobilization protocol involved the region of the enzyme surface containing the highest number of Lys residues. The formation of several bonds between each enzyme molecule and the support promotes the stabilization of the immobilized enzymes. [16].

The immobilized-stabilized derivatives of this endoxylanase were used to hydrolyze high concentrations of xylan (close to $1 \% \mathrm{w} / \mathrm{v}$ ) at high temperature (55 C) The rate and yield of the release of reducing sugars was studied. To determine the composition of XOS, the reaction products were chromatographically analyzed at different stages of the hydrolysis reaction. The exact composition of oligosaccharides of different reaction products was studied.

Materials and Methods

\section{Materials}

Agarose $10 \mathrm{BCL}$ was purchased from Agarose Bead Technologies (Madrid, Spain). Beechwood xylan, glycidol, sodium borohydride, sodium periodate, ethanolamine and 3-5'-dinitrosalicylic acid were obtained from Sigma-Aldrich Co (St. Louis. MO). CNBr-activated Sepharose and low molecular weight standards were purchased from GE Healthcare (Uppsala, Sweden) and the xylo-oligosaccharides standards were obtained from Megazyme (Wicklow, Ireland.). All reagents were analytical grade.

A protein molecular weight standard consisting of phosphorylase b (97 kDa), bovine serum albumin (66 kDa), ovalbumin (45 kDa), carbonic anhydrase (30 kDa), trypsin inhibitor (20.1 kDa) and $\alpha$-lactalbumin (14.4 kDa) was obtained from Sigma Chem. Co. 
Methods

All results represent the average of at least three experiments. The experimental error was never higher than $5 \%$.

S. lividans JI66 [17] was used as the host for the multicopy plasmid pNX4 [18]. The production of the xylanase for this strain was carried out in YES medium (1 \% yeast 
bovine serum albumin as the protein standard [20].

Purification of recombinant endoxylanase by adsorption on lowly activated Ni-IDA- 6

Lowly activated Ni-IDA-agarose gels (containing $10 \mu \mathrm{Eqs}$ of chelates per $\mathrm{mL}$ of $6 \%$ agarose gel) were prepared as previously described [21]. The crude endoxylanase extract was diluted 10 -fold in $50 \mathrm{mM}$ sodium phosphate buffer containing $150 \mathrm{mM}$ $\mathrm{NaCl}$ and $20 \mathrm{mM}$ of imidazole and adjusted to $\mathrm{pH}$ 7.0. Then, $150 \mathrm{mM} \mathrm{NaCl}$ was added to the binding buffer to prevent nonspecific ionic interactions between the non-recombinant proteins and the support.; $20 \mathrm{mM}$ imidazol was used to minimize the adsorption of non-recombinant proteins on the lowly activated Ni-IDA-supports, and $50 \mathrm{~mL}$ of the diluted crude endoxylanase extract $(0.8 \mathrm{mg} / \mathrm{mL}$ of protein concentration) were mixed with $1 \mathrm{~mL}$ of lowly activated Ni-IDA-agarose support [21]. The incubation was carried out at $25^{\circ} \mathrm{C}$ and under constant gentle magnetic stirring. After 1 hour, the enzyme was completely adsorbed onto the chromatographic support. Then, the adsorbed enzyme was recovered by filtration and subsequently washed with $50 \mathrm{~mL}$ of $50 \mathrm{mM}$ phosphate buffer at pH 7.0 containing $50 \mathrm{mM}$ imidazole and $150 \mathrm{mM} \mathrm{NaCl}$ to remove the traces of non-recombinant proteins that were adsorbed onto the support. Finally, the desorption of endoxylanase was performed by incubating the chromatographic support for $\mathbf{3 0}$ min with $50 \mathrm{~mL}$ of $\mathbf{5 0}$ $\mathrm{mM}$ phosphate buffer at $\mathrm{pH} 7.0$ containing $100 \mathrm{mM}$ imidazole and $150 \mathrm{mM} \mathrm{NaCl}$. The solution was dialyzed against distilled water and then lyophilized and stored in the refrigerator (it preserves fully active for 6 months). 
Activation of supports: Preparation of glyoxyl-agarose support

$105 \mathrm{~g}$ of $10 \%$ agarose beads were suspended in water to a final volume of $180 \mathrm{~mL}$ ( $0.7 \mathrm{~g}$ of agarose is roughly equivalent to $1 \mathrm{~mL})$. Following mild homogenization, $50 \mathrm{~mL}$ of $1.7 \mathrm{M} \mathrm{NaOH}$ containing $1.425 \mathrm{~g}$ of $\mathrm{NaBH}_{4}$ was slowly added. In an ice bath, $36 \mathrm{~mL}$ of glycidol were added drop-wise. The mixture was then gently stirred at room temperature for 18 hours, and the gel was finally washed with excess distilled water. Then, 10 wet $\mathbf{g}$ of glyceryl-activated gel was oxidized with $\mathbf{5 0}$ $\mathrm{mL}$ of aqueous $100 \mathrm{mM} \mathrm{NaIO}_{4}$ per $\mathrm{mL}$ of gel, and the oxidation was carried out under very gently stirring. After 2 hours, the gel was washed with distilled water and stored in the refrigerator at 4 Q $\mathrm{C}$ after vacuum drying (with the pores of agarose gels filled with water) [22].

\section{Stability of soluble enzyme at $\mathrm{pH} 10$}

Multipoint covalent immobilization has to be carried out at $\mathrm{pH} 10$. In order to establish the temperature of immobilization the stability of soluble enzyme was firstly studied. $0.2 \mathrm{mg}$ of enzyme were dissolved in $10 \mathrm{~mL}$ of $100 \mathrm{mM}$ sodium bicarbonate buffer at pH 10.0. The enzyme was incubated at 25 and 4 ? $\mathrm{C}$ and at different times aliquots were assayed as described above. According to the stability of soluble enzyme at $\mathrm{pH} \mathbf{1 0 . 0}$ the immobilization protocol was designed.

\section{Enzyme immobilization}

The immobilization on glyoxyl-agarose was performed by diluting up to $2 \mathrm{mg}$ of lyophilized xylanase to $50 \mathrm{~mL}$ of $100 \mathrm{mM}$ sodium bicarbonate solution at $\mathrm{pH} \mathbf{1 0 . 0}$ and 4 ? C Then, enzyme was added to $10 \mathrm{~g}$ of support, and the suspension was gently stirred at 4 ? C Periodically, samples of the supernatant and suspension were withdrawn, and the enzyme activity was measured. When the immobilization was 
completed ( 4 hours), the derivative was incubated at room temperature for 12 hours and finally it was reduced for 30 minutes with $1 \mathrm{mg} / \mathrm{mL}$ sodium borohydride.

On the other hand, very mild immobilization on CNBr-activated Sepharose was performed by using the same amount of enzyme diluted in a $100 \mathrm{mM}$ sodium phosphate buffer at $\mathrm{pH} 7.0$ and $4{ }^{\circ} \mathrm{C}$. After 15 minutes, the derivative was filtered and suspended into $1 \mathrm{M}$ ethanolamine solution at $\mathrm{pH} 8.0$ for 2 hours to block any remaining reactive group [23].

The yield of the immobilization was defined as the ratio between the activities in the supernatant compared with the activity in the blank of soluble enzyme. Expressed activity was defined as the ratio of the activity in the final suspension after the immobilization process and the initial activity of offered enzyme.

\section{Thermal stability studies}

$1 \mathrm{~g}$ of immobilized derivative was suspended in a $10 \mathrm{~mL}$ suspension containing $0.1 \mathrm{M}$ of acetate buffer $(\mathrm{pH} 5.0)$ or $0.1 \mathrm{M}$ of phosphate buffer (pH 7.0) at different temperatures. In all cases, at several time points, samples were withdrawn and their activity was tested as described above. The remaining activity was calculated as the ratio between activity at a given time and the activity at the start of the incubation.

SDS-PAGE

Samples underwent denaturing electrophoresis based on Laemmli's method [24] using $12 \%$ polyacrylamide gels. Gels were stained with Coomasie Blue. 
High-Performance Anion Exchange Chromatography with Pulsed Amperometric

214

215

216

217

Detection (HPAEC-PAD) analysis

Xylo-oligosaccharides (XOS) were analyzed with HPAEC-PAD using an ICS2500

Dionex system (Dionex Corporation, Sunnyvale, CA) consisting of a GP50 gradient pump, and ED50 electrochemical detector with a gold working electrode and $\mathrm{Ag} / \mathrm{AgCl}$ reference electrode. Data acquisition and processing was performed with the Chromeleon software version 6.7 (Dionex Corporation). For eluents preparation, MilliQ water (Milli-Q Synthesis A10 system; Millipore, Billerica, Mass., USA), $\mathrm{NaOH}$ (50\%, w/v) and NaOAc (Fluka, Germany) were used. All eluents were degassed by flushing with helium for $\mathbf{2 5}$ minutes.

Analyses were carried out at $25{ }^{\circ} \mathrm{C}$ on a CarboPac PA-1 column $(250 \times 4 \mathrm{~mm})$ in combination with a CarboPac PA-1 $(50 \times 4 \mathrm{~mm})$ guard column. Separations were performed at a flow rate of $1 \mathrm{~mL} / \mathrm{min}$. A gradient of $100 \mathrm{mM} \mathrm{NaOH}$ (eluent A) and $100 \mathrm{mM} \mathrm{NaOH}$ and $500 \mathrm{mM} \mathrm{NaOAc}$ (eluent B) was used (0-45 min, 0-70\% eluent B). After each run, the column was washed for 10 min with $100 \%$ of $100 \mathrm{mM} \mathrm{NaOH}$ and $1 \mathrm{M} \mathrm{NaOAc}$ (eluent C) and re-equilibrated for $15 \mathrm{~min}$ with the starting conditions of the employed gradient.

Before injection $(20 \mu \mathrm{L})$, samples and standard solutions were filtered through a nylon Millipore FH membrane $(0.22 \mu \mathrm{m})$ (Bedford, MA). The quantification of XOS was based on an external calibration using standard solutions of XOS (degree of polymerization from 1 to 6 ) and the calibration curve regression coefficients that were higher than 0.99. All analyses were carried out in duplicate, and data were expressed as the mean value. Standard deviation was never higher than $5 \%$. 
Purification of recombinant endoxylanase overexpressed in E. coli.

The recombinant endoxylanase was overexpressed and secreted to the culture medium. The crude extract was a fairly pure enzyme solution as analyzed with SDS-

PAGE (Figure 1, lane 2). A very selective adsorption of the enzyme (approx. $90 \%$ purity) on poorly activated nickel chelate supports in the presence of $20 \mathrm{mM}$ imidazole. Contaminant proteins were only adsorbed in trace amounts (data not shown) and were easily desorbed with a first wash with $50 \mathrm{mM}$ imidazole leaving the pure endoxylanase adsorbed onto the support (lane 3). Pure endoxylanase was eluted with $100 \mathrm{mM}$ imidazole. The purification yield was $95 \%$, and the purification factor was greater than 2 . The specific activity of the pure enzyme for the hydrolysis of xylan was $\mathbf{2 5 5} \mu \mathrm{mols}$ of released reducing sugars per minute per $\mathrm{mg}$ of protein.

It was only possible to purify the His-tagged recombinant protein to homogeneity in one step. Moreover, the selective adsorption of the target enzyme facilitates the use of small volumes of chromatographic support and therefore makes the purification only $20 \mathrm{~mL}$ of chromatographic support.

The pure enzyme was immobilized on CNBr-activated Sepharose. A very mild 256 immobilization was performed at $\mathrm{pH} 7.0,4{ }^{\circ} \mathrm{C}$ for 15 minutes. In this way, only $30 \%$ of the enzyme was immobilized, but any type of multipoint covalent attachment was 
avoided. In fact, this mildly immobilized derivative preserves the $100 \%$ activity that

259

260

261

262

263

264

265

266

267

268

269

270

271

272

273

274

275

276

277 was immobilized, and this derivative exhibits the same thermal stability as the pure and the diluted soluble enzyme. Both enzyme preparations exhibit a half-life of 10 hours when incubated at $45{ }^{\circ} \mathrm{C}$ and $\mathrm{pH}$ 5.0. This mildly immobilized derivative, xyl$\mathrm{CNBr}$-agarose, with the molecules of the enzyme fully dispersed inside a porous support, was used as a blank representing the properties of the native enzyme in the absence of any artifact (aggregations, interaction with hydrophobic interfaces of air bubbles, etc.). Xylanase immobilized on $\mathrm{CNBr}$-activated Sepharose and the soluble enzyme seem to be identical: e.g., showing the same activity and thermal stability. However the study of the behavior of native enzyme under more drastic experimental conditions (high temperatures, organic cosolvent, stirred tanks, etc.) is more accurate when using the mildly immobilized enzyme. Soluble enzyme may undergo artifacts: aggregations, interactions with hydrophobic interfaces and these artifacts are impossible with any enzyme immobilized on porous supports. When an enzyme is mildly immobilized on CNBr-activated Sepharose at pH 7.0, 4 a and 15 minutes the multipoint immobilization is almost impossible and the derivative fairly represents the immobilized native enzyme.

The pure enzyme was also immobilized by multipoint covalent immobilization on glyoxyl-agarose under alkaline conditions. The stability of the soluble enzyme at pH 10 in bicarbonate buffer was evaluated at both $25{ }^{\circ} \mathrm{C}$ and $4{ }^{\circ} \mathrm{C}$. At $25{ }^{\circ} \mathrm{C}$, the soluble enzyme was fairly unstable (half-life time of 2 hours). In contrast, the enzyme was very stable at $4^{\circ} \mathrm{C}$ and retained $98 \%$ activity after 2 hours. Very highly activated gels 
with $150 \mu$ mols of glyoxyl (small aliphatic aldehyde groups) per $\mathrm{mL}$ of $10 \%$-agarose gel (1.4 of wet grams) were used, and immobilization was carried out at pH 10 and 4 ${ }^{\circ}$ C. Furthermore, $95 \%$ of the applied enzyme was immobilized in 2 hours and, after 4 hours of subsequent incubation at $4{ }^{\circ} \mathrm{C}$, the immobilized derivative was incubated for 12 hours at $25{ }^{\circ} \mathrm{C}$ before borohydride reduction. The immobilized derivative (xylglyoxyl-agarose) retained $65 \%$ activity when compared to the soluble enzyme that had been immobilized on the support. In the present paper soluble dextran is always used. Now, the behavior of soluble and immobilized enzyme is very similar (e.g., at low temperatures). At 55 ? the soluble enzyme could not be studied because of its very low stability. On the contrary Lin et al [6] have compared the behavior of soluble and immobilized enzyme on a mixture of soluble and insoluble xylan. Immobilized enzyme was only able to act on the soluble fraction of xylan (shorter chains) and the soluble enzyme is also able to act on insoluble xylan (longer chains). In this way, the behavior of both enzyme preparations was clearly different. As remarked out in Introduction, we propose the use of immobilized enzymes in order to simplify the reactor design: use of continuous reactors, use of stirred tanks with very easy end of the controlled hydrolysis.

To evaluate the activity-stability properties of immobilized endoxylanase in the absence of diffusional limitations, the immobilized derivatives were firstly prepared with a low enzymatic loading (50 IU/mL of support). On the other hand, the highest loading capacity of glyoxyl-10\% agarose gels was evaluated and $75 \mathrm{mg}$ of the enzyme could be immobilized per $\mathrm{mL}$ of wet support ( 0.7 grams of wet agarose gels). This high loaded derivative exhibits an intrinsic activity of $12430 \mathrm{IU}$ per $\mathrm{mL}$ of derivative. Intrinsic activity was analyzed after breaking the derivative under strong 
magnetic stirring at $4{ }^{\circ} \mathrm{C}$. This strong stirring promotes a very high reduction of particle size of immobilized enzyme.

Both immobilized derivatives were incubated at $60{ }^{\circ} \mathrm{C}$ at $\mathrm{pH}$ 5.0. Xyl-glyoxyl-agarose exhibited a half-life of 15 days and xyl-CNBr-agarose had a half-life of less than 2 hours (Figure 2). Multipoint covalent immobilization promoted a stabilization that was more than 200 -fold higher than that of the one-point immobilized derivative. Stabilization was also observed in experiments of activity versus temperature. The

Hydrolysis of xylan by immobilized-stabilized endoxylanase 
327 stirring the suspensions were centrifuged and the amount of pellet was measured.

328 At $\mathbf{5 5}$ a the $\mathbf{5 0} \%$ of xylan is dissolved. At lower temperatures the solubility of

329 xylan is clearly lower: $30 \%$ at 25 and $20 \%$ at 4 a. The results were very similar

330 when solubility of xylan was measured by evaluating the decrease of "light

331 scattering" at $650 \mathrm{~nm}$ as a consequence of the solubilization of xylan.

332 The rate of the hydrolysis and the final yields increase as temperature increases

333 (Figure 5). The final yield achieved at $55^{\circ} \mathrm{C}$ after 140 hours was considered to be 100

$334 \%$ of release; $80 \%$ and $90 \%$ release of the reducing sugars were achieved after 3 and

5 reaction hours, respectively. The highest yield (100\%) was achieved after 140

hours. Furthermore, $90 \%$ hydrolysis was never achieved at $25{ }^{\circ} \mathrm{C}$ even after 140

hours. Both the hydrolysis rate and yield were decreased at $4{ }^{\circ} \mathrm{C}$. In Figure 5 the final degrees of hydrolysis are calculated by taking as $100 \%$ the reducing sugars hydrolyzed at 55 ? $\mathrm{C}$. The final yields of hydrolysis are very similar to the different solubilities. In this way, Figure 5 clearly shows the different rates of hydrolysis and the different xylan solubilities obtained at different temperatures.

Reuse of immobilized-stabilized xylanase

Because the immobilized-stabilized derivative was fairly stable at $60^{\circ} \mathrm{C}$, it seems that this derivative could be re-used for a number of reaction cycles at $50-55^{\circ} \mathrm{C}$. In Figure

6, we observe that enzymatic hydrolysis of xylan was unchanged after 10 reaction cycles (Figure 6). By using the high loaded derivative (75 $\mathrm{mg}$ of enzyme per $\mathrm{mL}$ of support), $80 \%$ of hydrolysis could be achieved in less than 10 minutes. 
351 The composition of the XOS mixtures was studied at different conversion degrees.

352 The enzyme seems to be an endoxylanase, and the release of xylose was minimal up 353 to the release of $80 \%$ of reducing sugars. However, at this conversion degree, $49 \%$ 354 of a XOS mixture (from xylobiose to xylohexose) was obtained (Table 1). This

\section{CONCLUSIONS}

The over-expression of the catalytic domain of endoxylanase from Streptomyces with the insertion of a poly-His tail allows for the easy preparation of a large amount of a pure industrial enzyme. This enzyme was immobilized and highly stabilized (200fold) by multipoint covalent attachment on glyoxyl-agarose. The maximal enzyme loading was $75 \mathrm{mg}$ (12000 Units) per $\mathrm{mL}$ of support. The stabilized and low loaded enzyme derivative $(0.2 \mathrm{mg}$ per $\mathrm{mL}$ of support) could be used to catalyze the hydrolysis of xylan at $55^{\circ} \mathrm{C}$. In only 3 hours the hydrolysis of $80 \%$ of $1 \%(w / v)$ xylan 
373 was achieved. After this hydrolysis a mixture of small prebiotic xylo-

374 oligosaccharides (containing $50 \%$ of XOS) was obtained. At higher conversion

375 degrees a $56 \%$ of xylobiose could be obtained.

\section{Acknowledgements}

377 This work has been supported by the Ministerio de Ciencia e Innovación, Spain

378 (Grant EUI2008-03631 from ERA-IB to R. I. Santamaría and Grant AGL-2009-07625 to

379 Jose M. Guisan). Gloria Fernández-Lorente is recipient of a Ramon y Cajal postdoctoral

380 Contract. Caio Aragon thanks Brazilian agencies FAPESP (2008/09332-8) and CAPES

$381 \quad(3756 / 10-6)$ for financial support. 
384 [1] Vazquez MJ, Alonso JL, Dominguez H. Xylooligosaccharides: manufacture and

[2] Courtin CM, Swennen K, Broekaert WF, Swennen $Q$, Buyse J, Decuypere E, Michiels CW, De Ketelaere B, Delcour JA. Effects of dietary inclusion of xylooligosaccharides, arabinoxylooligosaccharides and soluble arabinoxylan on the microbial composition of caecal contents of chickens. J Sci Food Agr 2008;88:2517-2522.

[3] Garrote G, Dominguez H, Parajo JC. Mild autohydrolysis and environmentally fiendly technology in xylooligosaccharide production from wood. J Chem Tech Biot 1999;74:1101-1109.

[4] Carmona EC, Fialho MB, Buchgnani EB, Coelho GD, Brocheto-Braga MR, Jorge JA. Production, purification and characterization of a minor form of xylanase from Aspergillus versicolor Process Biochem 2005;40:359-364.

[5] Ko C-H, Tsai C-H, Tu J, Lee H-Y, Ku L-T, Kuo P-A, Lai Y-K. Molecular cloning and characterization of a novel thermostable xylanase from Paenibacillus campinasensis BL11. Process Biochem 2010;45:1638-1644.

[6] Lin Y-S, Tseng M-J, Lee W-C. Production of xylooligosaccharides using immobilized endo-xylanase of Bacillus halodurans. Process Biochem 2011;46:2117-2121.

[7] Yuan X, Wang J, Yao H, Venant N. Separation and identification of endoxylanases from Bacillus subtilis and their actions on wheat bran insoluble dietary fibre. Process Biochem 2005;40:2339-2343.

[8] Akpinar O, Erdogan K, Bakir U, Yilmaz L. Comparison of acid and enzymatic hydrolysis of tobacco stalk xylan for preparation of xylooligosaccharides. LWT - Food sci Technol 2010;43:119-125.

[9] Polizeli ML, Rizzatti AC, Monti R, Terenzi HF, Jorge JA, Amorim DS. Xylanases from fungi: properties and industrial applications. Appl Microbiol Biot 2005;67:577-591.

[10] Beg QK, Kapoor M, Mahajan L, Hoondal GS. Microbial xylanases and their industrial applications: a review. Appl Microbiol Biot 2001;56:326-338.

[11] Khandeparker R, Numan MT. Bifunctional xylanases and their potential use in biotechnology. J Ind Microbiol Biot 2008;35:635-644.

[12] Ruiz-Arribas A, Fernández-Abalos JM, Garda AL, Sánchez P, Santamaría RI. Overproduction, purification and biochemical characterization of one xylanase (Xys1) from Streptomyces halstedii JM8. Appl Environ Microb 1995;61:2414-2419.

[13] Ruiz-Arribas A, Sanchez P, Calvete JJ, Raida M, Fernandez-Abalos JM, Santamaria RI. Analysis of $x y s A$, a gene from Streptomyces halstedii JM8 that encodes a 45-kilodalton modular xylanase, Xys1. Appl Environ Microb 1997;63:2983-2988.

[14] Ruiz-Arribas A, Zhadan GG, Kutyshenko VP, Santamaria RI, Cortijo M, Villar E, Fernandez-Abalos JM, Calvete JJ, Shnyrov VL. Thermodynamic stability of two variants of xylanase (Xys1) from Streptomyces halstedii JM8. Eur J Biochem 1998;253:462-468.

[15] Canals A, Vega MC, Gomis-Rüth FX, Díaz M, R.I. S, Coll M. Structure of xylanase Xys1 $\triangle$ from Streptomyces halstedii. Acta Crystallogr D 2003;D59:1447-1453.

[16] Mateo C, Palomo JM, Fuentes M, Betancor L, Grazu V, López-Gallego F, Pessela BCC, Hidalgo A, Fernández-Lorente G, Fernández-Lafuente R, Guisán JM. Glyoxyl agarose: A fully inert and hydrophilic support for immobilization and high stabilization of proteins. Enzyme Microb Tech 2006;39:274-280.

[17] Kieser T, Hopwood DA, Bibb JM, Chater KF, Buttner MJ. Practical Streptomyces genetics. Norwich, UK: John Innes Foundation; 2000. 
[18] Rodríguez S, Santamaría RI, Fernández-Ábalos JM, Díaz M. Identification of the sequences involved in the glucose-repressed transcription of the Streptomyces halstedii JM8 xysA promoter. Gene 2005;351:1-9.

[19] Miller GL. Use of dinitrosalicylic acid reagent for determination of reducing sugar. Anal Chem 1959;31:426-428.

[20] Bradford MM. A rapid and sensitive method for the quantitation of microgram quantities of protein utilizing the principle of protein dye binding. Anal Biochem 1976;72 248-254.

[21] Armisen P, Mateo C, Cortés E, Barredo JL, Salto F, Diez B, Rodés L, García JL, Fernández-Lafuente R, Guisán JM. Selective adsorption of poly-His tagged glutaryl acylase on tailor-made metal chelate supports. J Chromat A 1999;848:61-70.

[22] Guisán JM. Aldehyde-agarose gels as activated supports for immobilizationstabilization of enzymes. Enzyme Microb Tech 1988;10:375-382.

[23] Bolivar JM, Rocha-Martín J, Mateo C, Guisan JM. Stabilization of a highly active but unstable alcohol dehydrogenase from yeast using immobilization and postimmobilization techniques. Process Biochem 2012;47:679-686.

[24] Laemmli UK. Cleavage of structural proteins during the assembly of the head of bacteriophage T4. Nature, 1970;227:680-685.

[25] Blanco RM, Calvete JJ, Guisan JM. Immobilization-stabilization of enzymes; variables that control the intensity of the trypsin (amine)-agarose (aldehyde) multipoint attachment. Enzyme Microb Tech 1989;11:353-359.

[26] Mateo C, Palomo JM, Fuentes M, Betancor L, Grazu V, López-Gallego F, Pessela BCC, Hidalgo A, Fernández-Lorente G, Fernández-Lafuente R, Guisán JM. Glyoxyl agarose: a fully inert and hydrophilic support for immobilization and high stabilization of proteins. Enzyme Microb Tech 2006;39:274-280. 
460 molecular weight markers; (2) $10 \mu$ of supernatant of S. Lividans carrying the pNX4 plasmid; (3) purified endo-1,4- $\beta$-xylanase. Experiments were performed as described in the Methods.

Fig. 2. Time-courses of thermal inactivation of the immobilized endoxylanase derivatives. A.- Enzyme immobilized on $\mathrm{CNBr}$-activated Sepharose ( $\bullet$ )and B.- Enzyme Immobilized on glyoxyl-agarose $10 \mathrm{BCL}$ and on (a). Experiments were carried out at 60 ${ }^{\circ} \mathrm{C}$. The activity was measured at $25^{\circ} \mathrm{C}$ and at $\mathrm{pH} 5.0$ as described in the Methods.

Fig. 3. Influence of temperature on the enzymatic activity of immobilized endoxylanase: glyoxyl-agarose 10BCL derivatives (a), CNBr-activated Sepharose derivatives $(\diamond)$, soluble enzyme $(\diamond)$. Activity assays were performed at $\mathrm{pH}$ 5.0.

Fig. 4. Time-courses of thermal inactivation of immobilized endoxylanase at different

$474 \mathrm{pH}$ values. Glyoxyl-agarose $10 \mathrm{BCL}$ derivatives. ( $) \mathrm{pH}$ 5.0; (घ) pH 7.0. Experiments were 475 carried out at $75{ }^{\circ} \mathrm{C}$. The activity was measured at $25^{\circ} \mathrm{C}$ and $\mathrm{pH} 5.0$ as described In 476 Methods.

477 Experiments were done by triplicate. Experimental error was lower than 5\%. 
478 Fig. 5. Time courses of hydrolysis of beechwood xylan by endoxylanase immobilized on 479 glyoxyl-agarose $10 \mathrm{BCL}$ at different temperatures. 1 gram of xylan was added to $100 \mathrm{ml}$ 480 of buffer at different temperatures. The suspension was vigorously stirred for 2 hour 481 and then centrifuged ( $\bullet$ ) 4 Q (20\% of xylan dissolved) ; (a) 25 ?C (30\% of xylan 482 dissolved); ( $\boldsymbol{\Delta}$ ) 55 ? $\mathrm{C}$ ( $50 \%$ of xylan dissolved). Experiments were carried out at $\mathrm{pH}$ 483 5.0. $100 \%$ of reducing sugars are those measured at 55 ? $\mathrm{C}$.

484

Fig. 6. Ten consecutive cycles of hydrolysis of $1 \%(w / v)$ beechwood xylan by endoxylanase immobilized on glyoxyl-agarose 10BCL. Each reaction cycle was stopped when the immobilized derivative released $80 \%$ of reducing sugars. Experiments were carried out at pH 5.0 and 55 目.

Experiments were done by triplicate. Experimental error was lower than 5\%. 
510 Table 1. XOS formation after hydrolysis of $1 \%(w / v)$ beechwood xylan catalyzed by

511 endoxylanase immobilized on glyoxyl-agarose 10BCL

512

\begin{tabular}{|c|c|c|c|c|c|c|c|c|}
\hline \multirow{2}{*}{$\begin{array}{c}\text { Temperature } \\
\text { (回C) }\end{array}$} & \multirow{2}{*}{$\begin{array}{c}\text { Reducing } \\
\text { sugars } \\
(\%)\end{array}$} & \multicolumn{7}{|c|}{$\%$ total carbohydrates (w/w) } \\
\hline & & $\mathbf{X 1}$ & $\mathbf{X 2}$ & X3 & $\mathrm{X} 4$ & $\mathrm{X5}$ & $\mathrm{X6}$ & $\begin{array}{c}\text { Others } \\
\text { XOS }\end{array}$ \\
\hline- & $\begin{array}{c}4.4 \\
\text { (Control) }\end{array}$ & 0.00 & 0.00 & 0.00 & 2.43 & 4.18 & 7.98 & 86 \\
\hline \multirow[t]{4}{*}{55} & 38 & 0.00 & 12.13 & 8.39 & 7.31 & 4.42 & 3.29 & 65 \\
\hline & 64 & 0.21 & 17.18 & 11.17 & 7.32 & 4.46 & 3.01 & 57 \\
\hline & 80 & 0.53 & 22.65 & 12.92 & 7.17 & 3.73 & 2.23 & 50 \\
\hline & 100 & 10.82 & 56.07 & 0.96 & 0.40 & 0.23 & 0.24 & 30 \\
\hline
\end{tabular}




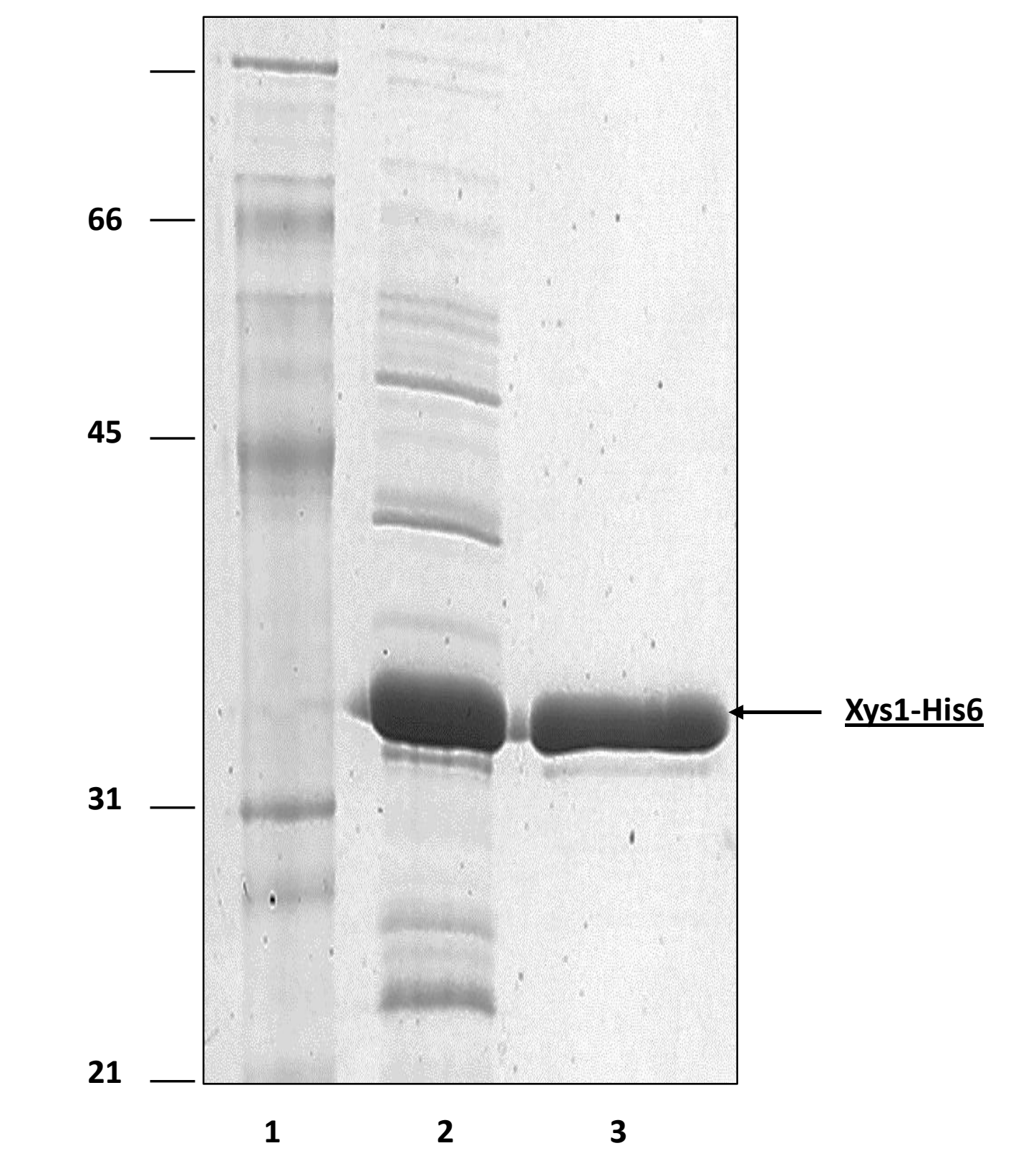

Figure 1

Figure(s)

\section{Figure(s) \\ Figure}

.

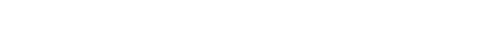



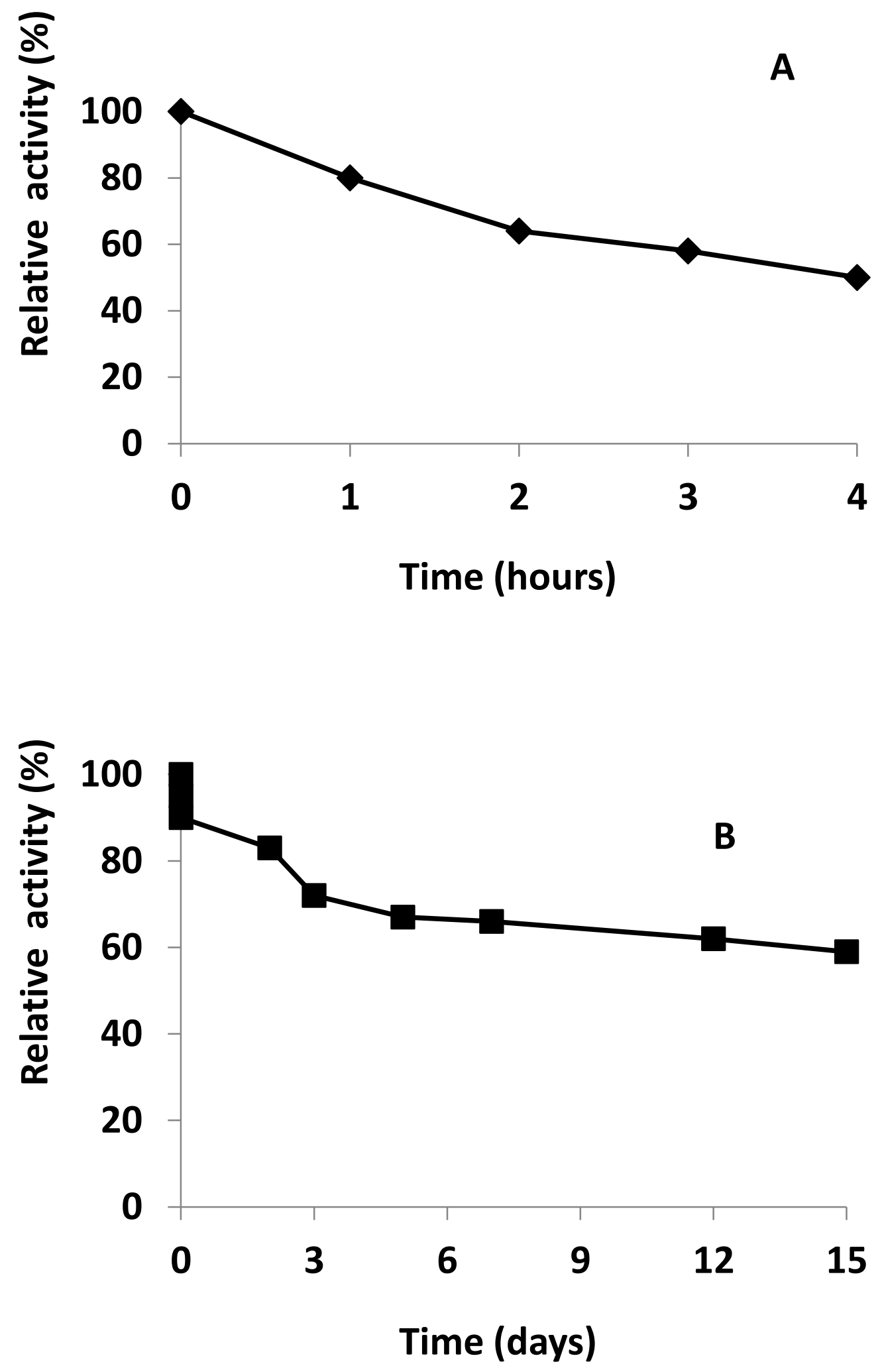

Figure 2 


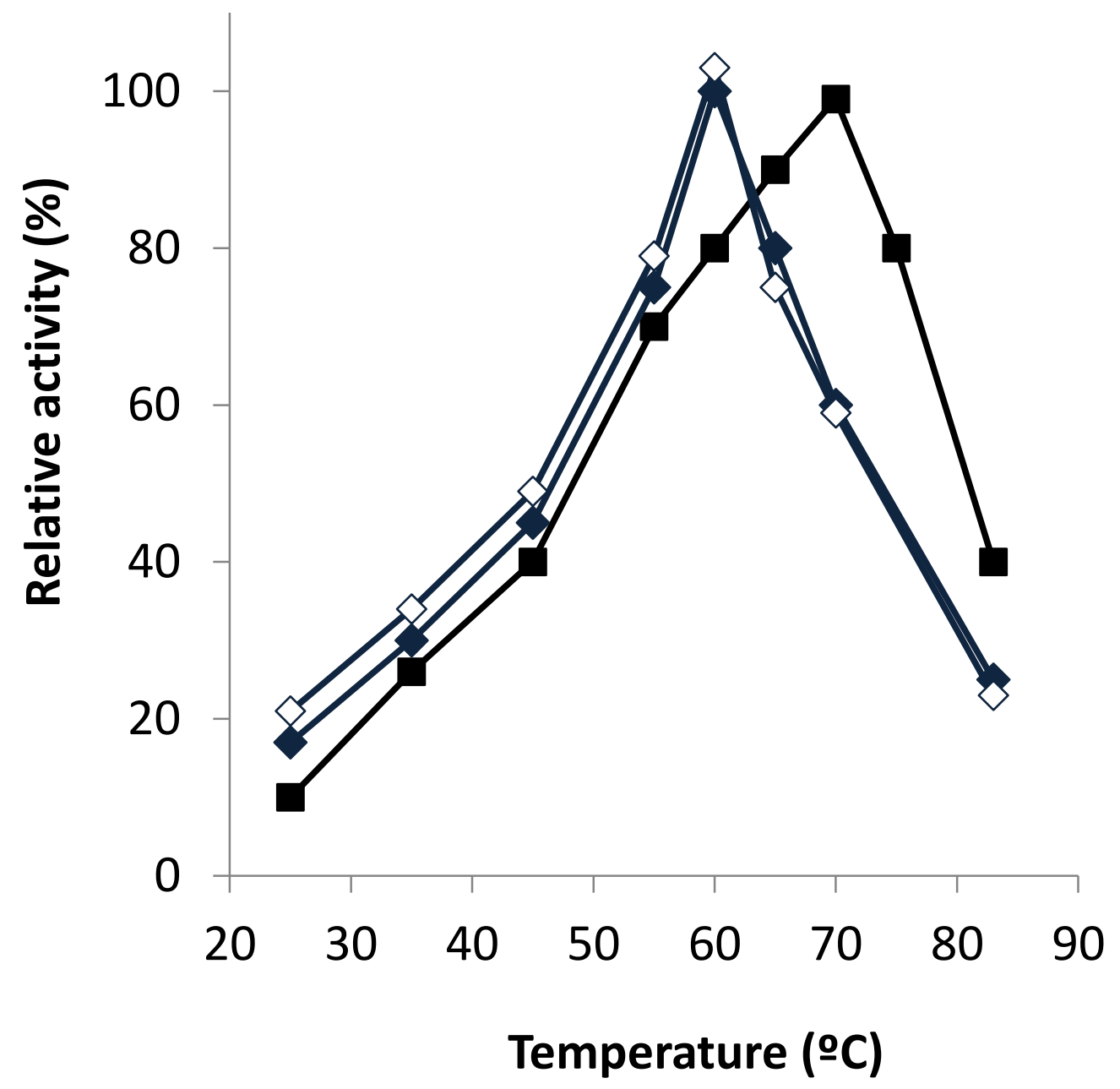

Figure3 


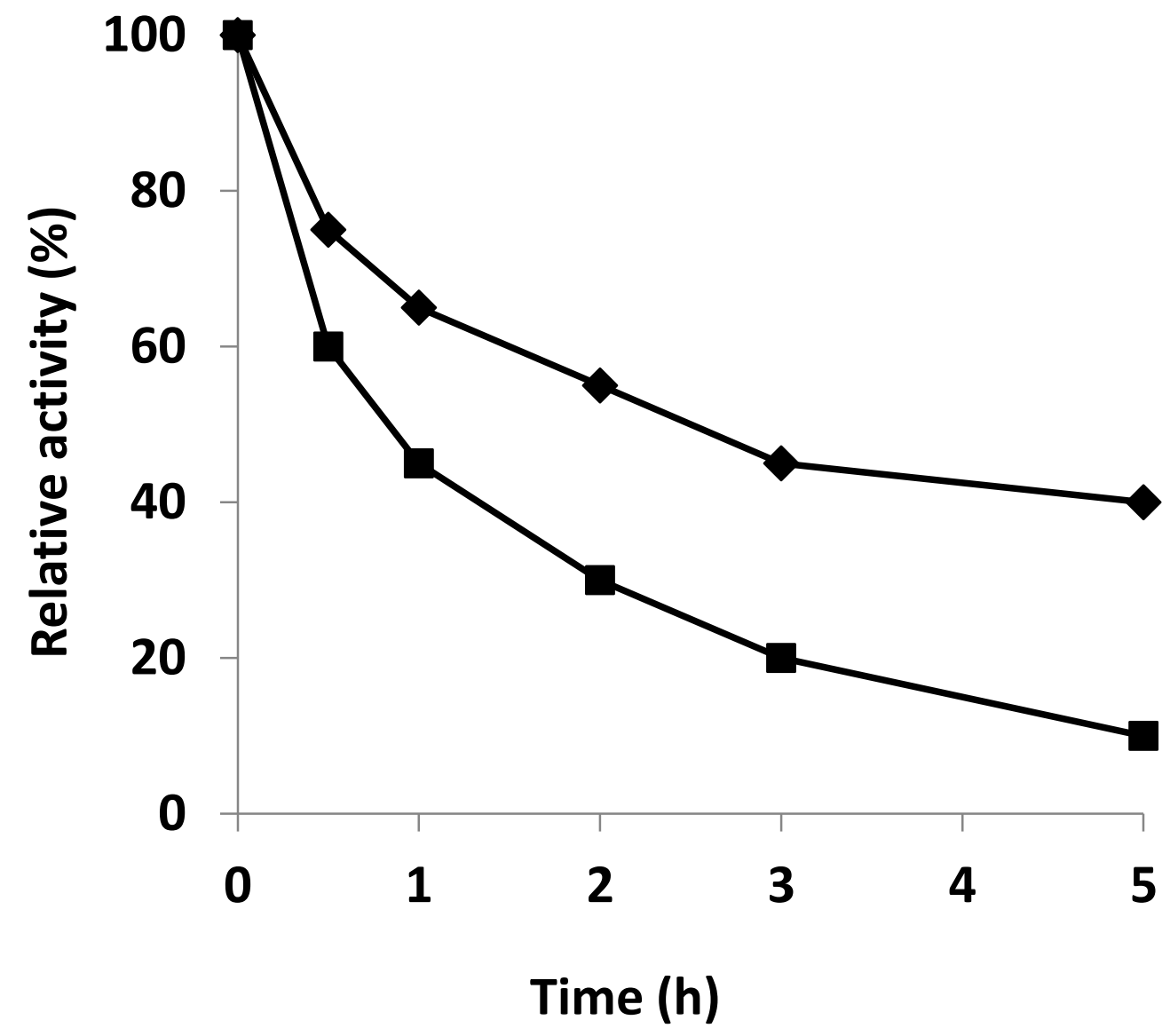

Figure 4 


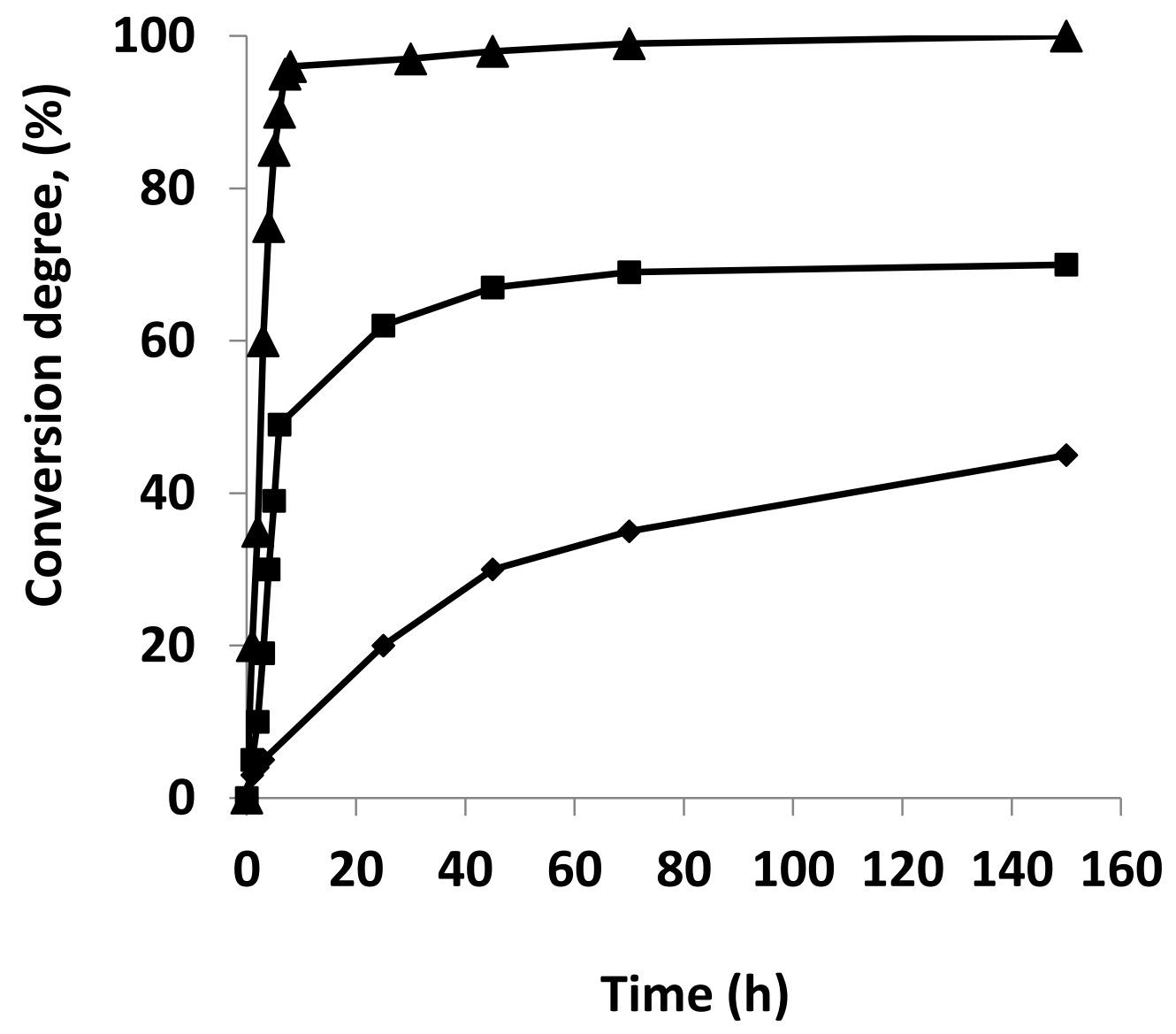

Figure 5 


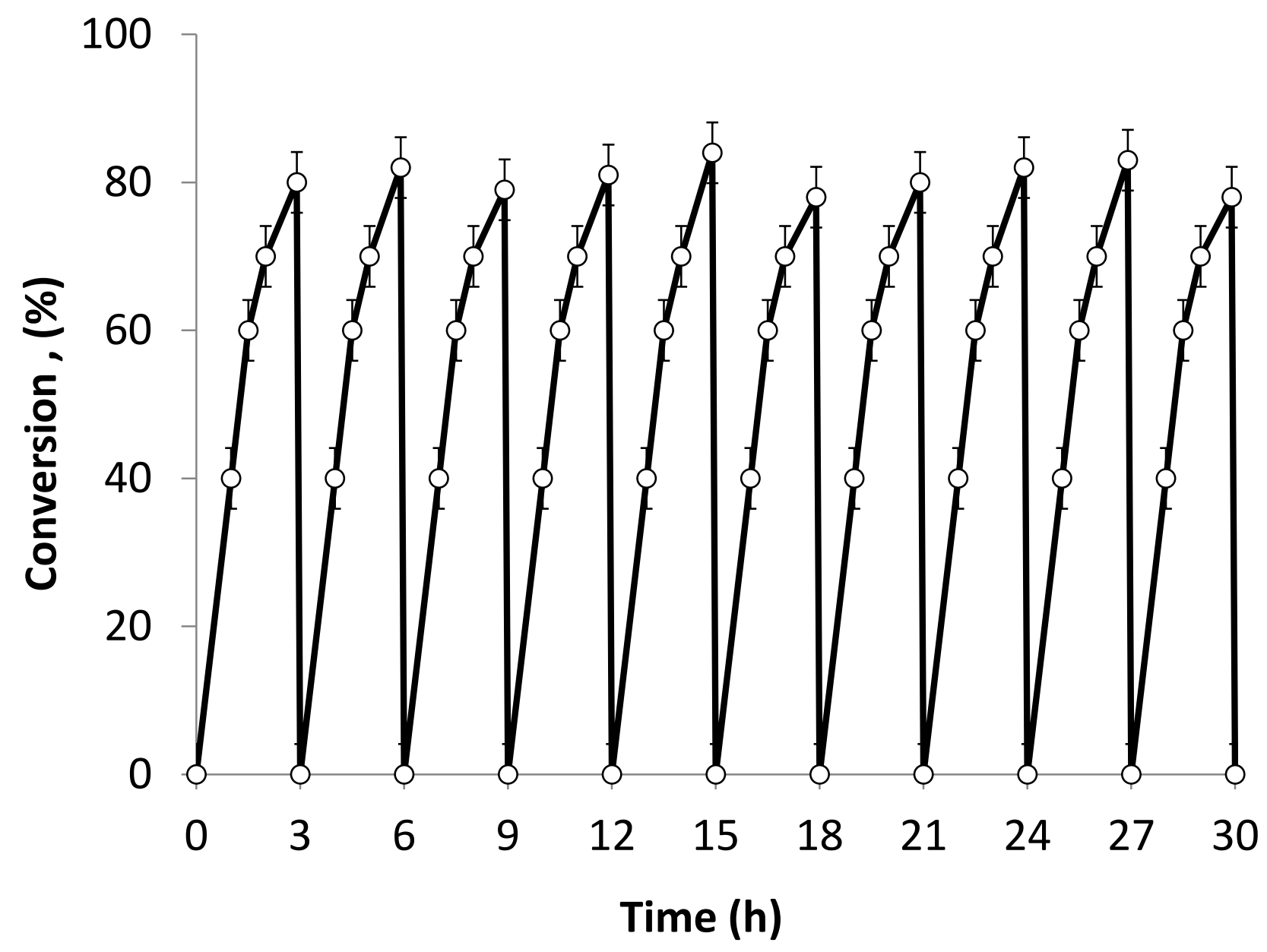

Figure 6 